\title{
Praise by Animals in the Hebrew Bible
}

\author{
Peter Joshua Atkins, University of Chester
}

\section{Introduction}

The concept of 'praise' itself is quite hard to locate with complete precision. In the context of the ancient Near East, praise was not just simply adoration but functioned as a response given to a specific god who had done what the subject wanted.1 Additionally, this praise was understood as part of a bargain between the god and the subject. If the deity responded in the way desired, then praise was given in return.2 Within the Hebrew Bible, praise is understood as only one aspect of the whole worship of the community, 3 clearly distinguished from the offering of sacrifices for example in Ps. 51.15-17 and 69.30-31. Yet these passages also refer to praise as being vocalised 4 and Walter Brueggemann argues praise is usually spoken or sung by the people. It typically begins with a summons to come and praise Yahweh, followed by an explanation of the reasons for why praise is to be offered.5

\footnotetext{
1 Morton Smith, 'The Common Theology of the Ancient Near East', JBL 71 (1952), pp. 135-147 (137). 2 J.J.M. Roberts, 'Divine Freedom and Cultic Manipulation in Israel and Mesopotamia', in H. Goedicke and J.J.M. Roberts (eds), Unity and Diversity: Essays in the History, Literature, and Religion of the Ancient Near East (Baltimore: Johns Hopkins University Press, 1975), pp. 181-90 (185).

3 Patrick D. Miller, "Enthroned on the Praises of Israel" The Praise of God in Old Testament Theology', Interpretation 39 (1985), pp. 5-19 (7).

4 This could be in either public or private contexts, see: Samuel E. Balentine, Prayer in the Hebrew Bible: The Drama of Divine-Human Dialogue (Overtures to Biblical Theology, 29; Minneapolis: Fortress Press, 1993), p. 214.

5 Walter Brueggemann, Worship in Ancient Israel: An Essential Guide (Nashville: Abingdon Press, 2005), p. 44.
} 
Scholars have typically been happy to attribute praise in the Hebrew Bible to more than simply human worshippers. Heavenly beings are also seen to offer praise to God (Ps. 29.1-2; 103.20; 148.2; Is. 6.1-4). Furthermore, most Hebrew Bible scholars admit the capacity to praise God extends into all of creation 6 and there is a growing scholarly discussion on the praise offered by the entirety of the created world.7 Texts which typify this creation praise are Psalm 148 and the Song of the Three Young Men in Daniel 3.2490, though this theme is found in many other Psalms. Creation praise includes the praise of humans, angels, animals, plants and inanimate creation because all have been made by God. This is commonly interpreted theologically and in such interpretations the inarticulate creation, including animals, praise merely by being what they were made to be. 8

Nevertheless, whilst commentators are willing to understand and appreciate the praise of humans or angels separately from this larger focus of non-vocal creation praise, the praise of animals has not been distinguished in this way. There has been severely

6 Walter Brueggemann, Israel's Praise: Doxology against Idolatry and Ideology (Philadelphia: Fortress, 1988), p. 1; Miller, "'Enthroned on the Praises of Israel"”, p. 14.

7 Notable assessments include: Terence E. Fretheim, 'Nature's Praise of God in the Psalms', Ex Auditu 3 (1987), pp. 16-30; Terence E. Fretheim, God and World in the Old Testament: A Relational Theology of Creation (Nashville: Abingdon Press, 2005), pp. 249-268; Richard Bauckham, 'Joining Creation's Praise', in Living with Other Creatures: Green Exegesis and Theology (Waco, Texas: Baylor University Press, 2011), pp. 147-162; Dominic Coad, 'Creation's Praise of God: A Proposal for a Theology of the Non-Human Creation', Theology 112 (2009), pp. 181-189; Jack D. Kilcrease, 'Creation's Praise: A Short Liturgical Reading of Genesis 1-2 and the book of Revelation', Pro Ecclesia 21 (2012), pp. 314-325.

${ }^{8}$ Daniel W. Hardy and David F. Ford, Praising and Knowing God (Philadelphia: Westminster Press, 1985), p. 82; Fretheim, 'Nature's Praise', p. 23. 
limited investigation into the place of animals with regards to praise.9 Sometimes, even the little investigation that there has been is actually focussed upon the entirety of creation's praise rather than just animals. 10 The most significant study carried out recently by Brent Strawn and Joel LeMon looks specifically at Psalm 150.6 and, while situating itself within the larger bracket of non-human praise, argues specifically for identifying only humans and animals in this verse. 11 A larger examination along similar lines has not been conducted across the entire Hebrew Bible. Animal praise has thus been addressed by scholars but normally only as a part of the wider creation and almost never as a subject of interest in its own right. This study aims to highlight this while showing how a variety of other Hebrew Bible texts evidence the idea that animals were capable of praising God too.

\section{The Place of Animals in the Hebrew Bible}

It is clear that, within the biblical texts, the animal world and God relate to one another in many and various ways. Animals appear to act as divine agents who obediently respond when God commands them to accomplish certain tasks: snakes are sent by

\footnotetext{
9 For a short but useful assessment of animal praise see: Ken Stone, Reading the Hebrew Bible with Animal Studies (Stanford, CA: Stanford University Press, 2018), p. 163 -163.

10 John Eaton, The Circle of Creation: Animals in the Light of the Bible (London: SCM Press, 1995), pp. 94-104.

11 Brent A. Strawn and Joel M. LeMon, “"Everything That Has Breath”: Animal praise in Psalm 150:6 in the light of ancient Near Eastern iconography', in Bilder als Quellen/Images as Sources: Studies on ancient Near Eastern artefacts and the Bible inspired by the work of Othmar Keel (eds. S. Bickel, S. Schroer, R. Schurte, and C. Uchlinger; OBO Sonderband; Fribourg: Academic Press, 2007), pp. 451-485.
} 
Yahweh to attack the Israelites (Num. 21.6) and God directly commands both a fish and a worm to act on his behalf (Jon. 1.17, 4.7). On numerous occasions this response becomes vocalised as animals cry out to God. The primary motivation for this cry appears to be hunger. Lions, ravens, and other animals call out for food from God (Job 38.41; Ps. 104.21, 27; Ps. 147.9) and during a drought both people and animals cry out to God in Joel 1.20. Additionally, in Jonah 3.7-8 when Nineveh is called to repent, both the humans and animals fast, are covered with sackcloth and cry out to God in repentance. These examples show how animals react vocally and personally to God in a similar way to human beings.

If animals beseech God for food and mercy then God must be capable of responding by either providing food for animals, or giving or withholding judgement on animals. Both these divine responses are evidenced in the Hebrew Bible. In Psalm 104 God provides water to quench the thirst of all wild animals (10-11), causes the grass to grow as food for cattle (14), and gives food to all who look to God for it (27-8). Likewise it is clear that God judges the animal world, as God decides to annihilate all flesh with the flood (Gen. 6.12-13) and afflicts the Egyptian livestock as well as its people with plagues (Ex. 8.17-18; 9.6, 22-25; 12.29). There is also evidence God shows mercy and relents from afflicting animals. Jonah makes it clear that God is willing to have mercy on those who repent (Jon. 3.10), specifically mentioning God's mercy on the animals (Jon. 4.11). These actions of God legitimate the cries of the animals. They cry for food because 
God might provide them with it; they cry in repentance because God might have mercy on them. If God dealt positively with humanity we should anticipate they would respond with praise for God's favourable answer. Due to the demonstrable relationship between God and animals, this expectation remains in the case of animals which should also reply with praise or thanksgiving for God's actions towards them.

As well as their relationship with God, animals are also particularly related to humanity in the Hebrew Bible. The ancient Israelites did make significant distinctions between parts of nature, and animals are not simply grouped with the inanimate world; instead there exists a greater degree of commonality between animals and humanity. Primarily, animals share a similar substance with humans. They are both made of flesh (בשר), this is something shared by only humans and animals within the created world. The external, fleshly nature of both the human and the animal puts them into a particular relationship around this term.12

They are both also called נפש היה (Gen. 1.20, 24; 2.7; 9.10, 12, 15-16; Lev. 11:10, 46; Ezek. 47.9). Despite differences appearing in English translations, this refers to both humans and animals equally as they share the same breath from God.13 נפש היה associates animals with humans and distinguishes them from the inanimate natural world.14 They are also closely related in both creation accounts: in Genesis 1.24-27 they are made

\footnotetext{
12 N.P. Bratsiotis, 'בשר', TDOT 2:327.

13 Theodore Hiebert, The Yahwist's Landscape: Nature and Religion in Early Israel (Oxford: Oxford University Press, 1996), p. 63.

14 H. Seebass, 'נפש', TDOT 9:516.
} 
together on the sixth day of creation; in Genesis 2.18-19 animals are made as helpers for the man. Whilst these passages do make a distinction between the two in that humans are made in the image of God (Gen. 1.27) and animals are deemed not satisfactory partners (Gen. 2.20), there is a much greater relatedness between animals and humans than with anything else.

Finally, there are biblical passages which neatly display the similarity between humans and animals, while also demonstrating the relationship between God and animals. Animals and humans alone join in specific actions to God. Together they are involved in making covenants with God (Gen. 9.9-10; Hos. 2.18-20) and together they shake at God's presence (Ezek. 38.20). These provide examples of only animals and humans reacting and responding to God. The idea that animals may, uniquely from the rest of creation, join with humanity in giving praise to God would fit as another of these actions.

\section{Animal Praise in the Ancient Near East}

Amongst the other cultures of the ancient Near East, there is already a wealth of evidence for the idea that animals could praise a deity. The ancient Sumerians spoke about praise in a fashion which appears to encompass more than merely humans. The 'Raising of the Hand Prayer' to Nanna Suen proclaims that 'all creatures [rejoice] when they see 
you.' 15 The sun-god Shamash is also said to be praised by all living things.16 These are only a few examples of the Sumerian literature where all living creatures react to the deity. These expressions of universal adoration do not refer specifically to animal praise but they do encompass it within an overarching creaturely praise.

The belief that animals would praise or worship a deity is found particularly strongly in the Ancient Egyptian texts. 17 This is hardly surprising, considering the prominent place animals held in Egyptian society as a whole. Animals were commonly depicted throughout Egyptian culture being frequently used in both hieroglyphics and in the cult where many of the gods were portrayed with the heads of animals. Furthermore, there was no privileged position for humanity over the animal world.18 The idea that humans may be in a better position to offer worship to their gods would have been foreign to the Ancient Egyptians. There was a much greater continuity between gods, humans and animals as evidenced in the Shabaka stone's statement that Ptah is at work in gods, people and various animals. 19

\footnotetext{
15 Walter Beyerlin, Near Eastern Religious Texts Relating to the Old Testament (OTL; trans. from 1975 German original; London: SCM Press, 1978), p. 105. See also the Prayer to Ishtar in: Adam Falkenstein and Wolfram von Soden, Sumerische und akkadische Hymnen und Gebete (Die Bibliothek der Alten Welt; Zurich: Artemis-Verlag, 1953), p. 329.

16 Falkenstein and von Soden, Sumerische, p. 242.

17 This is argued, amongst others, by: Emily Teeter, 'Animals in Egyptian Literature' in A History of the Animal World in the Ancient Near East (ed. Billie Jean Collins; HdO, 64; Leiden: Brill, 2002), pp. 251270 (274).

18 H. te Velde, 'A Few Remarks upon the Religious Significance of Animals in Ancient Egypt', Numen 27 (1980), pp. 76-82 (77).

19 English translation in: te Velde, 'A Few Remarks', p. 77.
} 
This phenomenon of animals praising or worshipping a deity is best expressed and displayed in the Egyptian beliefs surrounding baboons who were believed to worship the sun god. This belief concerning baboons is expressed on the curious Edifice of Taharqa by the Sacred Lake of Karnak which was built during the 25 th dynasty by the Kushite king Taharqa.20 A section of this edifice concerns the role of baboons in praising the sun:

The baboons that announce Re when this great god is to be born again about the sixth hour in the Netherworld. They appear for him after they have come into existence. They are at both sides of this god until he rises in the eastern horizon of the sky. They dance for him, they jump gaily for him, they sing for him, they sing praises for him, they shout for him.21

The baboons themselves are intimately connected to the praise of the sun, and this also expressed in the way they were depicted in illustrations and carvings. Baboons are present with their forepaws raised in an attitude of worship on obelisks which were symbols of the sun, and they were found on the eastern facades of structures to link them to the rising sun.22 Other depictions of the baboons worshipping the sun can be found, for example, on the Hypocephalus of Neshorpakhered the temple musician23 dated around the 4 th- 3 rd

\footnotetext{
${ }_{20}$ For a full discussion of the ritual function of the edifice see: Kathlyn M. Cooney, 'The Edifice of Taharqa by the Sacred Lake: Ritual Function and the Role of the King', Journal of the American Research Center in Egypt 37 (2000), pp. 15-47.

21 R.A. Parker, J. Leclant and J.C. Goyon, The Edifice of Taharqa by the Sacred Lake of Karnak, (London: Providence, 1979), p.46-7.

22 Richard H. Wilkinson, Reading Egyptian Art: A Hieroglyphic Guide to Ancient Egyptian Painting and Sculpture (London: Thames and Hudson, 1992), p.73.

23 Figure 85 in G. Pinch, Magic in Ancient Egypt (London: British Museum Press, 1994), pp.156-7.
} 
century BC; and the Papyrus of Anhai from the Book of the Dead which shows only human and animal figures honouring the heavenly falcon with the sun disc on its head.24

The praise of the baboons is not, however, merely subsidiary or in partnership with that of humans. Instead, 'Egyptians ... considered ... baboons as the ideal and true performers of religion.' 25 The worship offered by baboons was something to replicate or aspire to and was not a marginal aspect of Egyptian religion. It has been suggested that the cult and ritual of the Egyptians were basically a repetition of what the baboons were doing each morning.26 This elevated ideal of the baboons is displayed in chapter 100 of the Egyptian Book of the Dead which suggests the baboons' praise is something humans should aspire to join with. The speaker can boast that 'I have hymned and worshipped the solar disc, I have joined with him who is with the worshipping baboons, and I am one of them.'27 The baboons seem to be the exemplary religious actors for the Egyptians which even those who are dead are required to imitate.

However it is not only the baboons who praise deities in Egyptian thought. While baboons do have a special place in worship, other animals join in too. The Book of the Dead also contains the lines: 'Baboons give veneration to him, and with one voice small

${ }_{24}$ Figure 63 in Othmar Keel, The Symbolism of the Biblical World: Ancient Near East Iconography and the Book of Psalms (trans. from 1972 German original; London: SPCK, 1978), p.60

25 H. te Velde, 'Some Remarks on the Mysterious Language of the Baboons', in Funerary Symbols and Religion (eds. J.H. Kamstra, H. Milde and K. Wagtendonk; Kampen: J.H. Kok, 1988), pp. 129-137 (129). 26 te Velde, 'Some Remarks', p. 130.

27 Raymond O. Faulkner, The Ancient Egyptian Book of the Dead (London: British Museum Press, 1985), p. 98. 
creatures worship him.'28 This motif is also picked up in a selection of Ancient Egyptian hymnic material, for example in Akhenaten's Great Hymn: 'the birds flutter in their nests, raising their wings in worship before your spirit. All the lambs skip around, the birds and everything that flutters live because you have risen for them.' 29 Other animals express similar worship in the ninth strophe of the Hymn of a Thousand Strophes: 'the scaly creatures leap in the water, they come out from their pools, for love of him. The sheep and cattle skip before his presence. The birds dance with their wings.' 30 While perhaps not as well developed or as important to the Egyptian cult as the praise of baboons, praise by a greater range of animals is still strongly evidenced in these texts. This praise by animals alludes to specific acts of worship rather than the idea that merely living as an animal constitutes their praise. Ancient Near Eastern texts have often been used to help understand biblical poetic material by providing a further contextual lens through which to illuminate the text.31 The influence of such beliefs can be seen in the fact that depictions of worshipping baboons have been found even in the Israel/Palestine region.32 With such

${ }_{28}$ John L. Foster, Hymns, Prayers, and Songs: An Anthology of Ancient Egyptian Lyric Poetry (SBLWAWS, 8; ed. Susan Tower Hollis; Atlanta: Scholars Press, 1995), p. 64.

29 Beyerlin, Near Eastern, p. 18.

30 Beyerlin, Near Eastern, p. 20.

31 Examples of this are: Gerhard von Rad, 'Job XXXVIII and Ancient Egyptian Wisdom', in The Problem of the Hexateuch, and Other Essays (trans. from 1958 German original; Edinburgh: Oliver and Boyd, 1966), pp. 281-291; Delbert R. Hillers, 'A Study of Psalm 148', CBQ 40 (1978), pp. 323-334. 32 Othmar Keel, Corpus der Stempelsiegel-Amulette aus Palästina/Israel: Von den Anfängen bis zur Perserzeit, Katalog Band I: Von Tel Abu Fară̆ bis Atlit (Orbis Biblicus et Orientalis, Series Archaeologica, 13; Fribourg: Fribourg Academic Press, 1997), p. 72-73. 
a prominent and well attested belief permeating the area in which the Hebrew Bible was formulated, there is good reason to search in these texts for a similar phenomenon.

\section{Animal Praise in the Hebrew Bible}

Instances of praise attributed to animals in the Hebrew Bible are more frequent than would perhaps be suggested by the dearth of investigation into it. There are largely two major groupings of instances where animals are linked with praising God: the praise of animals as one part of the rest of the natural world within creation praise sections; and secondly there are verses which isolate animal praise together with humanity.

\section{Animal Praise within Creation Praise Sections}

As has been stated before, there are specific texts in the Old Testament which touch upon the idea that the entire natural world reacts in praise to God. These texts express the belief that God is the lord of everything so therefore praise offered to God must be universal too. 33 The necessary implication is that animals are incorporated within this creation praise, which is evidenced in two ways: they are sometimes explicitly mentioned, and elsewhere their inclusion is more implicit.

Firstly, there are some passages which contain explicit references to animals joining with the natural world in praise. Psalm 148 is perhaps the best example of the

33 Fretheim, God and World, p. 266. 
entire creation being called together to offer a hymn to God. The Psalmist almost exhaustively catalogues every created thing and calls it to praise God. It is no surprise then that 'wild animals and all cattle, creeping things and flying birds' (Ps 148.10) are included, as are sea monsters and the deeps in verse 7 . Whilst making no distinction between any of the participants in this song of praise, whether called from the heavens (e.g. sun, moon or angels) or from the earth (e.g. animals, mountains or people), animals are specifically indicated as being involved in praise here.

A remarkably similar expression is found in the Song of the Three Young Men, a Greek addition to Daniel (Dan. 3.24-90 LXX).34 This contains an even greater and more developed list of the created world. The song calls for 'you whales and all that swim in the waters ... all birds of the air... all wild animals and cattle' (Pr. Azar. 57-9) to bless the Lord. These passages which refer to each individual aspect of nature explicitly mention the fact that animals are called to praise their creator. Whilst there is nothing distinguishable about this praise in these contexts, it is made evident that animals are linked with praise in the Hebrew Bible.

In addition to explicit mentions of animals being involved in praise, there are further places to look which implicitly show the same sentiment and supplement this idea. There are some passages which sum up creation praise into a couple of lines rather than

\footnotetext{
${ }^{34}$ There is some debate over whether this is an adaptation of Psalm 148, see: Carey A. Moore, Daniel, Esther and Jeremiah: The Additions. A New Translation with Introduction and Commentary (AB, 44; New York: Doubleday, 1977), pp. 75-6.
} 
providing the comprehensive list of earlier hymns (Ps. 103.22; 145.10, 11; Tob. 8.5). These are simple summary statements of the creation praise which animals have been shown to be part of. Furthermore, there are other sets of general expressions of creation praise which concern the inhabitants of creation. 35 An example of such a statement is Psalm 96.11-12a: 'Let the heavens be glad, and let the earth rejoice; let the sea roar, and all that fills it; let the field exult, and everything in it'. By calling upon the inhabitants of all the different realms of creation these passages necessarily refer to animal life, so by implication animals are included within many calls to praise throughout the Hebrew Bible.

The texts analysed here show praise by animals is not a foreign idea to the Hebrew Bible. However, to use these creation texts alone does not sufficiently distinguish animal praise as being worthy of separate consideration. Further examples of animal praise in the biblical texts are thus required to justify specifically analysing this phenomenon separately from the praise of the inanimate creation.

\section{Animal and Human Praise}

The second set of references to animal praise in the Hebrew Bible are more precisely about animals joining with humanity. These occur outside typical 'creation

\footnotetext{
35 Examples include: 1 Chron. 16:32; Ps. 69:34; Is. 42:10 and Jer. 51:48. For a complete list of related passages see: Fretheim, God and World, pp. 267-8.
} 
praise' psalms and are closely connected with praise by humans. The importance of these passages is they show a type of praise which is offered by humans and animals but not by other creatures. There are four separate places where this is observed, all of which occur in either the book of Psalms or Isaiah. These can be split into three types of references and each will be dealt with separately.

\section{a. The Honour of the Wild Animals}

The first of these is contained in Is. 43.20 which states that 'the wild animals will honour' God. The majority of scholars are happy to see this verse as evidence for animals praising God, whether designating it as unconscious praise 36 or not.37 Nevertheless, there have been some voices expressing the view that it should be understood figuratively or only as a reference to the nullification of dangerous wild animals. $38 \mathrm{~A}$ more detailed

\footnotetext{
36 J. Skinner, The Book of the Prophet Isaiah: Chapters XL-LXVI (CBSC; Cambridge: Cambridge University Press, 1898), p. 47; Stephen Lee, Creation and Redemption in Isaiah 40-55 (Jian Dao Dissertation Series, 2; Hong Kong: Alliance Bible Seminary, 1995), p. 156.

37 John Goldingay and David Payne, A Critical and Exegetical Commentary on Isaiah 40-55 (ICC; London: T\&T Clark, 2005), p. 299; Richard J. Clifford, Fair Spoken and Persuading: An Interpretation of Second Isaiah (Theological Inquiries; New York: Paulist Press, 1984), p.105; Christopher R. North, The Second Isaiah: Introduction, Translation and Commentary to Chapter XL-LV (Oxford: Clarendon Press, 1964), p.126; Jan L. Koole, Isaiah Part 3 I Isaiah 40-48 (Historical Commentary on the Old Testament; Kampen: Kok Pharos, 1997), p. 334; John W. Olley, “The Wolf, the Lamb, and a Little Child": Transforming the Diverse Earth Community in Isaiah', in The Earth Story in the Psalms and the Prophets (eds Norman Habel; Sheffield: Sheffield Academic, 2001), pp. 219-229 (222-223).

${ }_{38}$ For arguments suggesting a figurative sense see: John N. Oswalt, The Book of Isaiah: Chapters 40-66 (NICOT; Cambridge: Eerdmans, 1998), p. 155; E. Hessler, 'Die Struktur der Bilder bei Deuterojesaja', Evangelische Theologie 25 (1965), pp. 349-69. Scholars who suggest it is about pacifying the wild animals are Joseph Blenkinsopp, Isaiah 40-55: A New Translation with Introduction and Commentary (AB, 19A; London: Doubleday, 2002), p. 228; Ulrich E. Simon, A Theology of Salvation: A Commentary on Isaiah 40-55 (London: SPCK, 1953), p. 107.
} 
evaluation of Isaiah 43.20 is therefore required to demonstrate the legitimacy of reading animal praise in this passage.

Firstly, the examples of animals which are mentioned in Is. 43.20 may betray the nature of the honour these wild animals give. The animals תנות יענה are and are associated with the mournful noises of the desert (Mic. 1.8; Job 30.28-9; Is. 13.21-2). It is these cries of mourning which are then transformed in Is. 43.20 into a song of praise. 39 Thus, by including בנות יענה and w an whe both associated with vocal cries, the author provides a hint at the response the wild animals are intended to give here. The transformation of the desert when God provides water similarly transforms the attitude of the animals. Understanding Is. 43.20 as an example of animals praising God makes sense of the typical associations made with the creatures mentioned here.

The second important word to examine is the verb denoting the action of the wild animals. The root of the verb used כבד Tבד. The Piel form, which it is in Is. 43.20, is best understood as meaning 'to honour' ${ }^{40}$ One of the theological uses for this word, when in relation to God, is to parallel a verb of praise. 41 This is exactly the situation present in Is. 43.20. The honour given by the wild animals is paralleled with the human response of praise (תהלה) in 43.21. This has happened previously in Isaiah too, in 42.8 and 12, both

\footnotetext{
39 Koole, Isaiah Part 3, p. 334.

40 DCH, IV:349-350.

41 C. Westermann, 'כבד', TLOT 2:595.
} 
times תהלה is paralleled with כבד. This suggests the honour offered to God by the wild animals is a parallel expression of praise to that which humans also offer.

Finally, it should be established that this passage does not refer to a more general theme of all creation giving praise to God but is specifically restricted to animals or living beings. The praise is triggered by God providing a river and a spring appearing in the wilderness (43.19). This affects only the animals and the people as God provides water for them both to drink. There is no mention of other aspects of creation and the thrust of the passage is not directed towards the universal effect of God's work. The response of the animals is directly paralleled with that of God's people who praise God for the provision of water. As Christopher North has contended, what can be stated from the present passage is 'man and beast could rejoice and praise God together'. 42

\section{b. All Flesh Praise}

There are also statements in both Isaiah and the Psalms which centre on 'all flesh' praising God. Is. 66.23 states 'from new moon to new moon, and from Sabbath to Sabbath, all flesh shall come to worship before me, says the LORD', and Ps. 145.21 similarly claims 'all flesh will bless his holy name forever and ever'. These two verses both express the sentiment that a group called 'all flesh' will honour God in some form.43

42 North, Second Isaiah, p. 126.

43 The exact verbs used here are different though (שחה in Isaiah 66:23; ברך in Psalm 145:21). 
Most commentators are content to restrict these 'all flesh' references to the human realm. 44 However, the precise formulation used in both Is. 66.23 and Ps. 145.21 is בשרך ('all flesh') which may be understood as either a whole body, all living creatures including people and animals, all animals, or all mankind.45 It seems very unlikely these verses refer to animals alone to the exclusion of humans, or to the whole physical human body either. This leaves the two alternatives of either all humans or all humans and animals. The use of כל בשר to refer to both humans and animals is by no means uncommon in the Hebrew Bible. There are numerous places where it undeniably denotes all living creatures including animals (Gen. 6.13, 17; 9.11, 15, 16, 17; Lev. 17.14; Num. 18.15; Ps. 136.25). In fact, it has been argued that if animals and humans are intended to be referred to together then the phrase which is normally utilised is 'all flesh'.46

Furthermore, the structure of Psalm 145.21 seems to suggest כל בשר encompasses a wider collection of subjects as the Psalm leads the reader from the individual praise of

44 On Isaiah 66:23 see: Edward J. Young, The Book of Isaiah: The English Text, with Introduction, Exposition, and Notes III Chapters 40 through 66 (NICOT; Grand Rapids: Eerdmans, 1972), p. 536; John D.W. Watts, Isaiah 34-66 (WBC, 25; Waco, Texas: Word Books, 1987), p. 365; A.S. Herbert, The Book of the Prophet Isaiah: Chapter 40-66 (Cambridge Bible Commentary; London: Cambridge University Press, 1973), p. 196-7; J.A. Motyer, Isaiah: An Introduction and Commentary (Tyndale Old Testament Commentaries; Leicester: IVP, 1999), p. 407. On Psalm 145:21 see: A.A. Anderson, The Book of Psalms II Psalms 73-150 (NCBC; London: Marshall, Morgan \& Scott, 1972), p. 940; Frank-Lother Hossfeld and Erich Zenger, Psalms 3: A Commentary on Psalms 101-150 (Hermeneia; trans. from 2008 German original; Minneapolis: Fortress, 2011), p. 664. Though there are some who see these texts as incorporating animals too: Leslie C. Allen, Psalms 101-150 (WBC, 21; Waco, Texas: Word Books, 1983), p. 299; Artur Weiser, The Psalms: A Commentary (OTL; trans. from 1959 German 5th rev. ed.; London: SCM Press, 1962), p. 828. 45 Bratsiotis, 'בשنר', TDOT 2:319.

46 Elijah J. Schochet, Animal Life in Jewish Tradition: Attitudes and Relationships (New York: Ktav, 1984), p. 10. 
the psalmist through progressively broader groupings.47 It would then make sense for the Psalm to conclude at verse 21 with the broadest category: humans and animals. Elsewhere it is made clear the Psalm is not solely about humanity: all creation is under Yahweh's mercy (Ps. 145.9); the entirety of creation praises him (Ps. 145.10); and Yahweh satisfies 'the desire of every living thing' (Psalm 145.16). The context seems to indicate that animals are included within the praise of 'all flesh' in Psalm 145.21.

Conversely, the context of Isaiah 66.23 has been used to deny that 'all flesh' refers to humans and animals. John Watts argues 'all flesh' is used in Is. 40.5-6 and 66.16 to describe Zion's congregation which represents all mankind.48 However, these verses do not necessarily refer just to humankind. The usage in Is. 40.6 for instance contrasts the eternally enduring nature of the word of God with transitory life, something shared by both humans and animals.49 Furthermore, when כל בשר is used in Is. 66.16 to describe Yahweh's judgment, it is not clear 'all flesh' refers to just humans here either. In the preceding verse, בשרך is used unequivocally about an animal (Isaiah 66.17 mentions eating swine's flesh); and when God judges 'all flesh' elsewhere it indicates both human and animal will be killed (Gen. 6.13, 17). Therefore, due to the word choice and topic of Isaiah 66, it is misleading to state that 'all flesh' must only refer to humans. Whilst neither

47 Nancy DeClaissé-Walford, 'Psalm 145: All Flesh Will Bless God’s Holy Name', CBQ 74 (2012), pp. 55-66 (59).

49 Anne E. Gardner, 'The Nature of the New Heavens and New Earth in Isaiah 66:22', ABR 50 (2002), pp. $10-27$ (14). 
Is. 66.23 or Ps. 145.21 explicitly mention animals, these two passages about 'all flesh' honouring God should be understood as including the praise of animals within their scope. They provide further evidence of the phenomenon of animals giving praise to God along with humans within the Hebrew Bible.

\section{c. Everything that Breathes Praises}

The final statement which links the praise of humans specifically with that of animals is found in Ps. 150.6. Here is the famous call to 'Let everything that breathes praise the LORD'. Discussion of this verse has caused some division amongst scholarship over who or what this group refers to, and of the three options proposed there seems to be an even split between them.50 The anthropocentric option argues Ps. 150.6 deals exclusively with human worshippers;51 others support the human-animal interpretation which specifically includes animals alongside humans in praise, 52 and the universal interpretation proposes all of creation is intended by the psalmist.53

\footnotetext{
50 For a previous summary of scholarly opinion on this passage see: Alma Brodersen, The End of the Psalter: Psalms 146-150 in the Masoretic Text, the Dead Sea Scrolls, and the Septuagint (BZAW 505; Berlin: De Gruyter, 2017), pp. 55-57.

51 Hossfeld and Zenger, Psalms 3, p. 663; Donatella Scaiola, 'The End of the Psalter', in The Composition of the Book of Psalms (ed. Erich Zenger; BETL 238; Leuven: Peeters, 2010), pp. 701-710 (710); Egbert Ballhorn, Zum Telos des Psalters: Der Textzusammenhang des Vierten und Fünften Psalmenbuches (Ps 90-150) (Berlin: Philo, 2004), p. 355.

52Terrien, The Psalms, p. 929; D.J. Human, “Praise beyond Words": Psalm 150 as grand finale of the crescendo in the Psalter', HTS Teologiese Studies/Theological Studies 67 (2011), pp. 1-10 (8-9); Derek Kidner, Psalms 73-150: A Commentary on Books II-V of the Psalms (TOTC; London: Inter-Varsity Press, 1975), p. 492; Strawn and LeMon, "Everything That Has Breath".

53 J.W. Rogerson, Psalms 101-150 (Cambridge: Cambridge University Press, 1977), p. 189; Allen, Psalms 101-150, p. 316; Hans-Joachim Kraus, Psalms 60-150: A Commentary (Minneapolis: Augsburg, 1989), p.
} 
The Hebrew term נשמה ('breath') is crucial for working out how to understand the passage and what place animals have here. It can be used about the breath of God (e.g. Ps. 18.16; Job 4.9; Is. 30.22), and about human breath (Is. 2.22; Aramaic Dan. 10.17). This human breath is found to originate from God who originally breathed it into them (Gen. 2.7; Job 32.8). It is because of such uses of the term that some scholars have been נed to see this breath as that which makes humans unique amongst animals.54 But נשמה is also used of animals (Gen. 7.22-23 is clear that both humans and animals are included) so breath can apply equally to human or animal.55 Furthermore, a different grasp can be gained from a deeper examination of what נשמה achieves. In Gen. 2.7 humans are created by turning dust into נפש היה by means of God providing נשמה While in this passage only humans receive God's breath, Strawn and LeMon have argued that it shows how animals must also have נששמה As animals are created as (Gen 2.19) it could mean they automatically have נשמה, and thus humans received it only secondarily as they were not created נפש היה but were originally dust. Following Strawn and LeMon's argument then, נשמה applies 'by default to the animal world and only derivatively to the

571; J.H. Eaton, Psalms: Introduction and Commentary (TBC; London: SCM Press, 1967), p. 316; Weiser, Psalms: Commentary, p. 841; Hans-Peter Mathys, 'Psalm CL', VT 50 (2000), pp. 329-344 (342-344).

54 T.C. Mitchell, 'The Old Testament Usage of NE ŠĀMÂ', VT 11 (1961), pp.177-87.

${ }_{55} \mathrm{DCH}, \mathrm{V}: 779$.

56 Hedwig Lamberty-Zielinski, 'נשמה', TDOT 10:67.

57 Strawn and LeMon, “"Everything That Has Breath”, pp. 454-455. 
human world.' 58 It can therefore be legitimately stated that נשמה does not 'account for any fundamental difference between human beings and the animal world.' 59

This can provide grounds to dismiss any suggestions that this verse concerns all creation praising God. There is no reason to see all creation here because plants and inanimate creation such as rocks have no connection to נשמה at all. While, purely speculatively, there may be justification for seeing the scope of Ps. 150.6 extend to heavenly angelic praise as well as that of humans and animals, 60 it is clear that this is not a typical example of creation praise.

One of the more prominent modern scholars advocating the anthropocentric reading is Erich Zenger who offers that breath should here be understood as 'breath that supports speech.' He appeals to Klaus Koch who suggested this type of breath forms the anthropological distinction. 61 This argument is further reinforced by other situations where נשמה unmistakably refers to this link with facilitating speech (Job 26.4 and in Aramaic Dan. 10.17). Zenger concludes that 'the reference is here to humans beings, who are living things capable of uttering the language of the Psalms.' 62 However, the biblical picture is not as simple as this. The serpent in the Garden of Eden (Gen. 3.1-5) and Balaam's donkey (Num. 22.28-30) both display the ability to speak. Indeed, the speech

\footnotetext{
58 Strawn and LeMon, "Everything That Has Breath", p. 455.

59 Lamberty-Zielinski, 'נשמה', TDOT 10:67.

60 Weiser, Psalms: Commentary, p. 841.

${ }_{61}$ Klaus Koch, 'Der Güter Gefährlichstes, die Sprache, dem Menschen gegeben... Überlegungen zu Gen 2:7’, BN 48 (1989), pp. 50-60.

62 Hossfeld and Zenger, Psalms 3, p. 663
} 
of the serpent seems to be an entirely unremarkable occurrence which suggests the capacity for intelligible language is something which some ancient people thought animals possessed.63 These passages complicate any simple assertion that 'breath that supports speech' is withheld from animals and would support the idea that animals were believed to be capable of articulating praise.

An analysis of נשמה has been important but the actual construction present in Ps. 150.6 is כל נשמה 'all breath'. It occurs five other times in the Hebrew Bible, however in each of these cases it refers to the destruction or death of breath in the herem tradition (Deut. 20.16; Josh. 10.40, 11.11, 14; $1 \mathrm{Kgs} 15.29)$. From these possible parallels it might be assumed that כל נשמה only refers to humans; for example, in Josh. 11.14 the Israelites take the livestock as spoil while still being able to state they have destroyed כל נשמה, which could only be true if animals were not included within 'all breath'. Yet, another parallel in Deut. 20.14 states livestock, children, and women may be taken as spoil, but must still be destroyed in the town (Deut. 20.16). If the same logic is applied here as in Josh. 11.14 then women and children are not included within כל נשמה either. A better reading of these passages is that the Israelites were able to take livestock, women, or children as spoil but whatever they chose to leave were then included in the נל נשמה that was destined to be destroyed. In other cases herem seems to have called for the 
destruction of animals (Josh. 6.21; Deut. 13.15; 1 Sam. 15.3), so it is possible that Josh.11.14 and similar passages merely clarify that here 'the ban did not or should not extend to animals'.64 There is thus no clear, legitimate reason animals should be denied inclusion within the grouping כל נשמה.

It is argued by some that the context in the Psalm suggests verse 6 should be understood anthropocentrically. 65 This mention of 'all breath' praising God follows immediately from verses listing musical instruments (150.3-5) which seems to indicate human recipients of this call for praise. However the inclusion of animals within this context is not actually out of place. Strawn and LeMon have provided ample evidence from Ancient Near Eastern iconography of how music is commonly combined with animals including examples of zoomorphic instruments and of animal musicians. 66 Indeed there is possible creation language in this Psalm too, e.g., the call to 'praise him in his mighty firmament' (Psalm 150.1), which may indicate other living creatures are called to worship.67 Psalm 150.6 therefore may provide a final example of animals being joined in praise together with humans.

\footnotetext{
64 Strawn and LeMon, "Everything That Has Breath"”, p. 456.

65 Ballhorn, Zum Telos des Psalters, p. 355.

66 Strawn and LeMon, "“Everything That Has Breath", pp. 462-473.

67 Stone, Reading the Hebrew Bible, p. 162-163; Strawn and LeMon, “"Everything That Has Breath"”, pp. 458.
} 


\section{Conclusion}

The presence of the praise of animals is clearly demonstrated across the Hebrew Bible. While sections of universal creation praise show that animals are overtly called to praise God, animal praise is not only restricted to these universal praise sections. Additionally and more crucially, animal praise is linked together with the praise of humanity in multiple contexts. Their praise is not reduced to the same level as the rest of the inanimate world but animals respond with praise to God which is only given by animate beings. Shared characteristics (e.g., flesh, breath) distinguish animals and humans from the inanimate world. The praise of animals is thus not entirely reducible to the praise of all creation, but is instead a more nuanced phenomenon. While not as developed or noticeable as animal praise elsewhere in the ancient Near East, there are several important texts which display a related belief.

The idea that animals had the capacity to praise God is, from the total of evidence here provided, one which should be taken seriously when reflecting upon the Hebrew Bible tradition. In the ancient Near East animals occupy a distinct niche in the whole vision of praise or worship, and in the Hebrew Bible animals are found to have a particular relationship with God and share a level of commonality with humanity. Both of these set them apart from inanimate creation and further increase the expectation that animals may be capable of praise. Animal praise is, in actuality, fairly common in the biblical text. 
The implication of this then is that it is therefore not satisfactory to only analyse the praise of the natural world. Humans and angels, while included within creation praise psalms, are commonly seen as offering praise outside of this context and this study has suggested that animals should be included in this separate grouping as well. The praise of animals is something distinct and different from that of inanimate creatures. Modern readers may not share the belief that animals have the capacity to praise God audibly but it would be a mistake to allow such preconceptions to restrict their understanding of biblical passages. 